\title{
Chemical composition and bioactivity of essential oils and Ethanolic extracts of Ocimum basilicum L. and Thymus algeriensis Boiss. \& Reut. from the Algerian Saharan Atlas
}

Maria Rezzoug ${ }^{1}$, Boulanouar Bakchiche', Abdelaziz Gherib', Ascrizzi Roberta², FlaminiGuido², Özge Kilinçarslan³, Ramazan Mammadov ${ }^{3}$ and Sanaa K. Bardaweel ${ }^{4^{*}}$ (D)

\begin{abstract}
Background: There is increasing interest in the pharmaceutical and food industries to substitute synthetic chemicals with naturally occurring compounds possessing bioactive properties. Plants are valuable sources of bioactive compounds. The present study investigates the chemical composition and antioxidant, antimicrobial, and anticancer activities of ethanolic extracts (EEs) and essential oils (EOs) from two species in the Lamiaceae family, Ocimum basilicum L. and Thymus algeriensis Boiss. \& Reut., cultivated in the Algerian Saharan Atlas.

Methods: The total flavonoid contents of the plants' ethanolic extracts were determined by the aluminium chloride method, while the total phenols were determined using the Folin-Ciocalteu method. Essential oils were obtained by hydrodistillation of the aerial parts of the plants and were analysed by GC-MS. The free radical-scavenging ability and antioxidant potential of the plants' EEs and EOs were probed using the 2, 2-diphenyl-picrylhydrazyl radical-scavenging, ABTS radical-scavenging, ferric-reducing power and phosphomolybdenum assays. The antimicrobial activities were evaluated against several pathogens characteristic of gram-negative bacteria (three species), gram-positive bacteria (three species) and fungi (two species). The microdilution method was used to estimate the minimum inhibitory concentrations (MICs). The oils' anticancer potential against several cancer types was also studied using the MTT assay and reported as the toxic doses that resulted in a 50\% reduction in cancer cell growth $\left(\mathrm{LD}_{50}\right)$.
\end{abstract}

Results: Phenolic compounds in the EEs from both plants were analysed by HPLC and demonstrated a rich flavonoid content. Chemical analysis of the essential oil from Ocimum basilicum revealed 26 unique compounds, with linalool (52.1\%) and linalyl acetate (19.1\%) as the major compounds. A total of 29 compounds were identified in the essential oil from Thymus algeriensis, with a-terpinyl acetate (47.4\%), neryl acetate (9.6\%), and a-pinene (6.8\%) as the major compounds. The ethanolic extracts and essential oils from both plants exhibited moderate antioxidant activities and moderate to weak antimicrobial activities. Furthermore, anticancer activities against the examined human cancer cell lines were associated with only the EOs from both plants, with $\mathrm{LD}_{50}$ values ranging between 300 and $1000 \mu \mathrm{g} / \mathrm{mL}$.

\footnotetext{
* Correspondence: S.bardaweel@ju.edu.jo

${ }^{4}$ Department of Pharmaceutical Sciences, School of Pharmacy, The University

of Jordan, Queen Rania Street, Amman 11942, Jordan

Full list of author information is available at the end of the article
}

(c) The Author(s). 2019 Open Access This article is distributed under the terms of the Creative Commons Attribution 4.0 International License (http://creativecommons.org/licenses/by/4.0/), which permits unrestricted use, distribution, and reproduction in any medium, provided you give appropriate credit to the original author(s) and the source, provide a link to the Creative Commons license, and indicate if changes were made. The Creative Commons Public Domain Dedication waiver (http://creativecommons.org/publicdomain/zero/1.0/) applies to the data made available in this article, unless otherwise stated. 
(Continued from previous page)

Conclusion: The results suggest that the bioactive compounds found in the ethanolic extracts and essential oils from

Ocimum basilicum and Thymus algeriensis, with diverse antioxidant, antimicrobial and anticancer activities, may have

beneficial applications in nutraceutical and pharmaceutical technologies.

Keywords: Ocimum basilicum, Thymus algeriensis, Essential oil, Ethanolic extract, Antioxidant activity, Antimicrobial activity, Anticancer activity

\section{Background}

Among the numerous medicinal plants, some prevalent species are particularly popular in folk medicine due to their antioxidant properties and health benefits [1]. The Lamiaceae family is one of the most extensively studied plant families containing members with proven human health benefits. Antimicrobial [2-4], antioxidant [5, 6], anti-inflammatory, anti-depressive, and antiproliferative effects $[7,8]$ have been demonstrated for the active compounds found in many plants from this family. Rosemary, thyme, basil, and sage are famous members of the Lamiaceae family and are among the most commonly used plants in traditional Mediterranean remedies, mainly for the treatment of gastritis, infections, dermatitis, bronchitis, and inflammation $[3,4,9,10]$.

Ocimum basilicum, an aromatic herb that belongs to the Lamiaceae family and the Nepetoideae subfamily [9], has been used in folk medicine for the treatment of gastrointestinal and respiratory diseases [10]. This species was also reported as having beneficial effects on kidney malfunctions, warts and worm infestations [10]. Various chemical functionalities characteristic of anthocyanins, flavonoids, monoterpenes, phenolic acids and their esters, phenylpropanoid derivatives, phytosterols, tannins, and triterpenes have been identified in different O. basilicum extracts [11, 12]. Essential oils extracted from its leaves and flowers can be used as flavouring agents in food, medicine and cosmetics $[10,11]$.

Another renowned genus of the Lamiaceae family is the Thymus genus. It contains approximately 215 to 350 species that are remarkably predominant in the Mediterranean area $[13,14]$. The aerial parts and the volatile components of Thymus species are traditionally used as herbal teas and condiments and for numerous medicinal purposes, e.g., as antispasmodic, antibacterial, antiviral, expectorant and antioxidant agents [15]. Compounds in several classes have been identified in Thymus species, such as carvacrol, thymol, geraniol, $\gamma$-terpineol, thujone and linalool [16].

The aim of this study was to investigate the chemical composition and biological activities of essential oils and ethanolic extracts from Ocimum basilicum and Thymus algeriensis cultivated in the Algerian Saharan Atlas (Laghouat region).

\section{Materials and methods Plant materials}

Ocimum basilicum and Thymus algeriensis were harvested in their flowering stage between April and May 2016 in the area of the Algerian Saharan Atlas (Laghouat region). The species were characterized at the Department of Biology, Faculty of Science, University of Laghouat (Algeria), and the voucher specimens were banked at the Laboratory of Process Engineering, University of Laghouat, with the numbers LGP Ob/04/16 and LGP Ta/05/16, respectively. The plant materials were air-dried for 15 days and stored at room temperature $\left(25 \pm 2{ }^{\circ} \mathrm{C}\right)$ without exposure to direct sunlight.

\section{Preparation of the ethanolic extracts}

Dried plant aerial parts (leaves) were pulverized. Each $15 \mathrm{~g}$ of ground sample was placed into a separate Erlenmeyer flask. Then, $100 \mathrm{~mL}$ of ethanol (100\%) was added, and the samples were incubated in a water bath at $55^{\circ} \mathrm{C}$ for $6 \mathrm{~h}$. Separation of the extraction mixture from the residue was achieved by filtration through Whatman No. 1 filter paper. Each plant residue was re-extracted in triplicate with ethanol. After filtration, the two portions were mixed. The residual solvent in the ethanolic extracts were removed under reduced pressure at $48-49^{\circ} \mathrm{C}$ using a rotary evaporator (Rotavapor IKA VB 10, Germany). Water in the extracts was lyophilized using a freeze dryer (Thermo Savant Modulyo D, USA) for $8 \mathrm{~h}$ at $-50^{\circ} \mathrm{C}$ and 0.040 mbar. The yields of these fractions were $20.16 \%$ (Ocimum basilicum) and $15.78 \%$ (Thymus algeriensis).

\section{Total phenolic content}

The total phenolic content was determined with FolinCiocalteu reagent using the method described by Singleton et al. [17]. Briefly, to $200 \mu \mathrm{L}$ of each sample (three replicates), $1 \mathrm{~mL}$ of $10 \%(\mathrm{v} / \mathrm{v})$ Folin-Ciocalteu reagent and $800 \mu \mathrm{L}$ of $\mathrm{Na}_{2} \mathrm{CO}_{3}(7.5 \%$, w/v) were added and incubated at $25^{\circ} \mathrm{C}$ for $30 \mathrm{~min}$. The absorbance of each sample was measured at $760 \mathrm{~nm}$ using a spectrophotometer (OPTIZEN $2120 \mathrm{UV})$. An ethanol solution of gallic acid was tested in parallel to obtain a calibration curve. Values were expressed as milligrams of gallic acid equivalents per gram of dry weight (mg GAE/g dry weight). 


\section{Total flavonoid content}

The total flavonoid content was estimated using the aluminium chloride colorimetric method of Boulanouar et al. [18]. Briefly, $1 \mathrm{~mL}$ of diluted extract was mixed with $1 \mathrm{~mL}$ of a $2 \% \mathrm{AlCl}_{3}$ methanol solution. After incubation at room temperature for $15 \mathrm{~min}$, the absorbance was measured at $430 \mathrm{~nm}$ using a spectrophotometer (OPTIZEN $2120 \mathrm{UV}$ ). The total flavonoid content was calculated from the calibration curve of rutin and expressed as milligrams of rutin equivalents per gram of dry weight (mg RE/g dry weight).

\section{Analysis of phenolic contents by HPLC}

The HPLC procedure described by Caponio et al. [19] was adopted for the analysis of phenolic contents. The conditions utilized were as follows: a C-18 column (CTO-10ASVp, $4.6 \mathrm{~mm} \times 250 \mathrm{~mm}, 5 \mu \mathrm{M}$ ), an injection volume of $20 \mu \mathrm{L}$, a mobile phase composed of solvent $\mathrm{A}$ (3\% formic acid in distilled water) and solvent B (100\% acetonitrile), gradient elution from 15 to $100 \%$ B over a run time of $45 \mathrm{~min}$ at a flow rate of $1 \mathrm{~mL} / \mathrm{min}$, and a UV-Vis detector. For analysis, the samples were dissolved in ethanol, and $20 \mu \mathrm{L}$ of this solution was injected into the column. Chromatograms were plotted based on detection at $280 \mathrm{~nm}$ with the UV-Vis detector. The retention times and UV absorption spectra of the phenolic compounds were compared with those of pure standards. Gallic acid, 3, 4-dihydroxybenzoic acid, 4hydroxybenzoic acid, 2, 5-dihydroxybenzoic acid, chlorogenic acid, vanillic acid, caffeic acid, p-coumaric acid, ferulic acid, rutin, ellagic acid, naringin, and quercetin were used as standards. Peaks were identified by matching the retention times and UV spectra with those of the standards. The quantity of each phenolic compound was reported in $\mu \mathrm{g}$ per gram of the extract.

\section{Isolation of essential oils}

Essential oils were extracted from the air-dried and ground plants (100 g each) using the hydrodistillation method for $4 \mathrm{~h}$ in a Clevenger-type apparatus. The obtained essential oils were dried over anhydrous sodium sulfate and stored at $4{ }^{\circ} \mathrm{C}$ in the dark until further analysis.

\section{GC-MS analysis}

GC-EIMS analyses were accomplished with a Varian CP3800 gas chromatograph equipped with a DB- 5 capillary column $(30 \mathrm{~m} \times 0.25 \mathrm{~mm}$; coating thickness of $0.25 \mu \mathrm{m})$ and a Varian Saturn 2000 ion trap mass detector. The following analytical specifications were used: injector and transfer line temperatures of $220^{\circ} \mathrm{C}$ and $240^{\circ} \mathrm{C}$, respectively; oven temperature programmed from $60^{\circ} \mathrm{C}$ to $240^{\circ} \mathrm{C}$ at $3{ }^{\circ} \mathrm{C} / \mathrm{min}$; carrier gas of helium at $1 \mathrm{~mL} / \mathrm{min}$; injection volume of $0.2 \mu \mathrm{L}$ (10\% hexane solution); and split ratio of 1:30. For the identification of each compound, a comparison of the retention times with the standards' retention times was performed. In addition, we evaluated the linear retention indices in relation to the retention times of a series of $n$-hydrocarbons and used computer-aided matching with commercially available mass spectra and mass spectra contained in an inhouse library.

\section{Antioxidant activities \\ Free radical-scavenging activity}

The DPPH radical-scavenging capacity was measured as previously described by Boulanouar et al. [18]. In this study, $1 \mathrm{~mL}$ of either ethanolic extract or essential oil was added to $2 \mathrm{~mL}$ of a $60 \mu \mathrm{M}$ DPPH methanol solution, and the reaction mixture was kept at room temperature and away from light for $30 \mathrm{~min}$ before the absorbance was recorded at $517 \mathrm{~nm}$. The following equation was used to estimate the scavenging activity: scavenging effect $(\%)=\left[100 *\left(A_{c}-A_{s} / A_{c}\right)\right]$, where $A_{c}$ is the control sample absorbance and $A_{s}$ is the test sample absorbance. The concentration of oil or extract at which $50 \%$ of the DPPH radicals $\left(\mathrm{IC}_{50}\right)$ were scavenged was calculated. Ascorbic acid was employed as a reference compound.

\section{ABTS assay}

The antioxidant capacity was estimated following the procedure described by Re et al. [20] with minor modifications. In brief, a $7 \mathrm{mM}$ ABTS stock solution was reacted with $2.45 \mathrm{mM}$ potassium persulfate at room temperature for $12-16 \mathrm{~h}$ while protected from light to produce the ABTS radical cation $\left(\mathrm{ABTS}^{*+}\right)$. The $\mathrm{ABTS}^{*+}$ mixture $(1450 \mu \mathrm{L})$ was diluted with methanol to reach an absorbance of $0.70 \pm 0.02$ at $734 \mathrm{~nm}$, followed by the addition of $50 \mu \mathrm{L}$ of either the test sample or Trolox standard and incubation at room temperature while protected from light for $6 \mathrm{~min}$. The absorbance was read at $734 \mathrm{~nm}$ using a spectrophotometer (OPTIZEN 2120 UV). For each test sample, the percent inhibition of $\mathrm{ABTS}^{*+}$ was computed using the following formula: (\% inhibition $)=\left[100 *\left(\mathrm{~A}_{\mathrm{c}}-\mathrm{A}_{\mathrm{s}} / \mathrm{A}_{\mathrm{c}}\right)\right]$, where $\mathrm{A}_{\mathrm{c}}$ is the control sample absorbance and $A_{s}$ is the test sample absorbance. The concentration of oil or extract that could scavenge $50 \%$ of the ABTS radicals $\left(\mathrm{IC}_{50}\right)$ was calculated. Trolox was used as a reference compound.

\section{Reducing power assay}

The method of Oyaizu 1986 was adopted to determine the reducing power of the examined EEs and EOs [21]. Extract solution $(0.1 \mathrm{~mL})$, phosphate buffer $(2 \mathrm{~mL}, 0.2 \mathrm{M}$, $\mathrm{pH}$ 6.6) and potassium ferricyanide $\left[\mathrm{K}_{3} \mathrm{Fe}(\mathrm{CN})_{6}\right](2 \mathrm{~mL}$, $1 \%$ ) were mixed and then incubated at $50^{\circ} \mathrm{C}$ for $20 \mathrm{~min}$. Afterward, $2 \mathrm{~mL}$ of trichloroacetic acid (10\%) was added to the solution to terminate the reaction. The mixture was then centrifuged at $3000 \mathrm{rpm}$ for $10 \mathrm{~min}$, and the 
upper layer of the solution $(2 \mathrm{~mL})$ was collected. The collected layer was mixed with distilled water $(2.5 \mathrm{~mL})$ and $\mathrm{FeCl}_{3}(0.5 \mathrm{~mL}, 0.1 \%)$ before the absorbance was measured at $700 \mathrm{~nm}$. Greater reducing power was associated with increased absorbance of the reaction mixture. The results are expressed in terms of the ascorbic acid equivalent antioxidant capacity (AEAC).

\section{Phosphomolybdenum assay}

The Prieto et al. method was adopted to evaluate the reducing capacity of the EEs and EOs from the two assessed plants [22]. In summary, $0.3 \mathrm{~mL}$ of each diluted extract was added to $3 \mathrm{~mL}$ of a phosphomolybdic reagent solution containing ammonium molybdate $(4 \mathrm{M})$, sodium phosphate $(28 \mathrm{mM})$ and sulfuric acid $(0.6 \mathrm{M})$. The mixture was placed in a water bath at a temperature of $95^{\circ} \mathrm{C}$ for $90 \mathrm{~min}$. After cooling to room temperature, the absorbance was measured at $695 \mathrm{~nm}$ against a blank solution containing $0.3 \mathrm{~mL}$ of ethanol mixed with $3 \mathrm{~mL}$ of phosphomolybdic reagent. The results are expressed in terms of the ascorbic acid equivalent antioxidant capacity $(\mathrm{AEAC})$.

\section{Antimicrobial activity Microorganisms}

Six bacterial and two fungal species were acquired from the Microbial Culture Collection Center of the Medical School at the University of Jordan, Jordan. The species used were Staphylococcus epidermidis ATCC12228 (grampositive bacterium), Staphylococcus aureus ATCC25923 (gram-positive bacterium), Bacillus subtilis ATCC11562 (gram-positive bacterium), Escherichia coli ATCC29425 (gram-negative bacterium), Pseudomonas aeruginosa ATCC15442 (gram-negative bacterium), Klebsiella pneumoniae ATCC43816 (gram-negative bacterium), Candida glabrata ATCC22553 (fungus), and Candida albicans ATCC10231 (fungus). The eight microorganisms represent predominant food pathogens that are frequently encountered [23-25].

\section{MIC determination}

Measurements of the minimum inhibitory concentration (MIC), defined as the minimum concentration at which more than $80 \%$ of the microbial growth is restrained, were performed in 96 flat-bottom microtiter plates (TPP, Switzerland) in accordance with the microdilution method, as previously reported by Bardaweel et al. [23]. An inoculum volume of $1 \times 10^{5} \mathrm{CFU} \mathrm{mL}^{-1}$ for each microorganism was used in each microtiter plate well. Ampicillin and amphotericin B (positive controls), as well as media (negative control), were employed under comparable experimental conditions. Plates containing bacteria were placed in a shaker incubator for $48 \mathrm{~h}$ at $37^{\circ} \mathrm{C}$, whereas plates containing Candida were incubated in the shaker for $48 \mathrm{~h}$ at $33^{\circ} \mathrm{C}$. To assess microbial growth, optical densities were read at $600 \mathrm{~nm}\left(\mathrm{OD}_{600}\right)$ using a microplate reader (Palo Alto, CA, USA).

\section{Anticancer activity Cell lines and cell viability}

All cancer cell lines used in this study (MCF7, MDAMB-231 HeLa, PC3, and K562) were acquired from the American Type Culture Collection (Rockville, MD, USA). All cells were cultured in Dulbecco's modified Eagle's medium (DMEM) supplemented with $10 \%$ foetal bovine serum, $100 \mathrm{U} / \mathrm{mL}$ penicillin, and $100 \mu \mathrm{g} / \mathrm{mL}$ streptomycin at $37^{\circ} \mathrm{C}$ with $5 \% \mathrm{CO}_{2}$. The count of viable cells was determined using the trypan blue method [24].

\section{MTT assay}

The anticancer activity of the phenolic extracts and essential oils were studied in 96-well round-bottom microplates using the MTT (3-[4, 5-dimethylthiazole-2-yl]-2, 5-diphenyl-tetrazolium bromide) assay (Sigma-Aldrich, USA) as previously described by Bouziane et al. [25]. In summary, cells were seeded in 96-well plates at a cell density of $1 \times 10^{4}$ cells $/ \mathrm{mL}$ and incubated for $24 \mathrm{~h}$ to permit attachment. Each well was treated with different concentrations $(0.001-1000 \mu \mathrm{g} / \mathrm{mL})$ of the prepared extracts in triplicate and incubated for $48 \mathrm{~h}$. Subsequently, $10 \mu \mathrm{L}$ of $0.5 \mathrm{mg} / \mathrm{mL}$ MTT was added to each well and further incubated for $4 \mathrm{~h}$ before measuring the absorbance at $570 \mathrm{~nm}$. Growth inhibition was determined based on the following equation: inhibition $(\%)=100$ (mean Abs of test sample - mean Abs of negative control) $\times 100 /$ (mean Abs of positive control-mean Abs of negative control). Graph Pad Prism 7 software (GraphPad Software, Inc., La Jolla, CA, USA) was used for data analysis to determine the inhibition percentage, and the results are presented as the $\mathrm{LD}_{50}$ value, described as the concentration that produces $50 \%$ growth suppression. The positive control doxorubicin was employed under the same experimental conditions.

\section{Data analysis}

For all experiments, the analyses were performed in triplicate, and the values are reported as the mean \pm standard deviation (SD). The results were analysed via Student's ttest, with $\alpha=0.05$. The analyses were carried out using IBM SPSS Statistics for Windows, version 22.0. (IBM Corp., Armonk, New York, USA).

\section{Results and discussion}

\section{Total phenolic and flavonoid contents}

The total phenol contents of extracts estimated by the Folin-Ciocalteu procedure and the total flavonoid contents estimated by the $\mathrm{AlCl}_{3}$ method are presented in Table 1 . The ethanolic extract of O. basilicum had the 
Table 1 Total phenolic and flavonoids contents in the ethanolic extracts of Ocimum basilicum and Thymus algeriensis

\begin{tabular}{lll}
\hline Plant & $\begin{array}{l}\text { phenolic content } \\
\text { (mg/g extract) }\end{array}$ & $\begin{array}{l}\text { flavonoid content } \\
\text { (mg/g extract) }\end{array}$ \\
\hline Ocimum basilicum & $226 \pm 2$ & $213 \pm 3$ \\
Thymus algeriensis & $125 \pm 1$ & $118 \pm 1$ \\
\hline
\end{tabular}

highest phenolic compound content and flavonoid content $(226 \mathrm{mg} / \mathrm{g}$, gallic acid equivalents, and $213 \mathrm{mg} / \mathrm{g}$, rutin equivalents).

\section{Identification of phenolic compounds by HPLC}

In this study, 15 phenolic compounds in the ethanolic extracts of $O$. basilicum and T. algeriensis were investigated by HPLC. The concentrations of the identified polyphenolic compounds in all analysed samples are presented in Table 2 (shown in the order of their retention time). The data in Table 2 revealed that the ethanolic extract of $O$. basilicum had high amounts of rutin, epicatechin and vanillic acid: $476.28 \mu \mathrm{g} / \mathrm{g}, 225.01 \mu \mathrm{g} / \mathrm{g}$, and $138.24 \mu \mathrm{g} / \mathrm{g}$, respectively. Two phenolic compounds, quercetin $(0.36 \mu \mathrm{g} / \mathrm{g})$ and caffeic acid $(6.48 \mu \mathrm{g} / \mathrm{g})$, were found in low concentrations. In the T. algeriensis ethanolic extract, six compounds were detected in notably high concentrations: epicatechin (major compound; $824.79 \mu \mathrm{g} / \mathrm{g}$ ), 2, 5-dihydroxybenzoic acid $(778.76 \mu \mathrm{g} / \mathrm{g})$, ellagic acid $(374.58 \mu \mathrm{g} / \mathrm{g})$, rutin

Table 2 HPLC analysis of ethanolic extracts for phenolic compound contents

\begin{tabular}{llll}
\hline $\begin{array}{l}\text { Phenolic standard } \\
\text { compounds }\end{array}$ & $\begin{array}{l}\text { Standard retention } \\
\text { time RT }(\mathrm{min})\end{array}$ & $\begin{array}{l}\text { Ocimum } \\
\text { basilicum } \\
(\mu \mathrm{g} / \mathrm{g})\end{array}$ & $\begin{array}{l}\text { Thymus } \\
\text { algeriensis } \\
(\mu \mathrm{g} / \mathrm{g})\end{array}$ \\
\hline $\begin{array}{l}\text { Gallic acid } \\
\begin{array}{l}\text { 3,4-dihydroxy benzoic } \\
\text { acid }\end{array}\end{array}$ & 10.7 & 21.61 & 10.49 \\
$\begin{array}{l}\text { 4-hydroxy benzoic } \\
\text { acid }\end{array}$ & 15.7 & 46.29 & 1.42 \\
2,5 dihydroxybenzoic & 17.2 & 52.14 & 10.03 \\
acid & & & 778.76 \\
Chlorogenic acid & 18.2 & 25.11 & 22.68 \\
Vanillic acid & 19.2 & 138.24 & 182.67 \\
Epicatechin & 21.3 & 225.01 & 824.79 \\
Caffeic acid & 22.7 & 6.48 & 33.30 \\
p-coumaric acid & 26.1 & 12.83 & 83.80 \\
Ferulic acid & 30.1 & 25.00 & 34.30 \\
Rutin & 45.6 & 476.28 & 280.39 \\
Ellagic & 47.7 & 27.64 & 374.58 \\
Naringin & 49.7 & 21.02 & 120.67 \\
Quercetin & 70.4 & 0.36 & 2.84 \\
Cinnamic acid & 71.1 & 54.68 & 20.51 \\
\hline
\end{tabular}

$(280.39 \mu \mathrm{g} / \mathrm{g})$, vanillic acid $(182.67 \mu \mathrm{g} / \mathrm{g})$, and naringin $(120.67 \mu \mathrm{g} / \mathrm{g})$. Epicatechin was found to be the major compound in the Thymus algeriensis ethanolic extract $(824.79 \mu \mathrm{g} / \mathrm{g})$, and 3, 4-dihydroxybenzoic acid was detected in the lowest concentration $(1.42 \mu \mathrm{g} / \mathrm{g})$. Nonetheless, to the best of our knowledge, HPLC identification of phenolic compounds from Thymus algeriensis has never been previously reported.

\section{Essential oil yield and chemical composition}

The yields of the essential oils under study were 1.05 and $0.51 \%$ for $O$. basilicum and $T$. algeriensis, respectively. Chromatographic analyses resulted in the identification of 61 compounds, representing 98.3\% (O. basilicum) and 96.5\% (T. algeriensis) of the essential oils (Table 3 ). These compounds were grouped into six chemical classes: monoterpene hydrocarbons, oxygenated monoterpenes, sesquiterpene hydrocarbons, oxygenated sesquiterpenes, apocarotenes, and non-terpene derivatives.

In the essential oil of $O$. basilicum, 26 compounds were identified, accounting for $98.3 \%$ of the oil. Interestingly, the content of oxygenated monoterpenes (92.0\%) was 23 times greater than that of monoterpene hydrocarbons (4.0\%). Linalool (52.1\%) and linalyl acetate (19.1\%) were detected as the major compounds in the oil. The composition of the essential oil of O. basilicum is extremely variable because of the existence of several chemotypes, i.e., linalool, methyl chavicol, eugenol, methyl eugenol and neral are the main compounds [26]. The essential oil obtained in the present study can be classified as a linalool-linalyl acetate chemotype, a characteristic chemotype of European basil [26].

In the $T$. algeriensis essential oil, 29 compounds were identified, of which $74.7 \%$ were oxygenated monoterpenes and $15.6 \%$ were monoterpene hydrocarbons. Among the minor compounds, oxygenated sesquiterpene (4.4\%) was characterized. The major compounds in T. algeriensis EO were $\alpha$-terpinyl acetate $(47.4 \%)$, neryl acetate $(9.6 \%)$, and $\alpha$-pinene $(6.8 \%)$. The main compounds in essential oil from $T$. algeriensis from different geographical areas have been frequently reported to include camphor and/or $\alpha$ pinene, while thymol and linalool have been occasionally reported as the main compounds [27]. Interestingly, the chemical composition of the T. algeriensis essential oil reported in this study appears to be unique, as $\alpha$-terpinyl acetate and neryl acetate were detected as the major compounds in the oil but thymol was not detected at all.

\section{Antioxidant activities DPPH assay}

$\mathrm{DPPH}$ is a stable radical that appears purple in solution and has an absorbance maximum at $515 \mathrm{~nm}$. Upon reduction, its colour changes into yellow with a concomitant decrease in absorbance at $515 \mathrm{~nm}$. The colour change is 
Table 3 Chemical composition of the essential oils extracted from the leaves of O. basilicum and T. algeriensis

\begin{tabular}{|c|c|c|c|c|}
\hline Constituents & LRI & $\begin{array}{l}\text { O. basilicum } \\
\text { (\%) }\end{array}$ & $\begin{array}{l}\text { T. algeriensis } \\
\text { (\%) }\end{array}$ & Method of identification ${ }^{b}$ \\
\hline a-pinene & 941 & 0.3 & 6.8 & MS; LRI; RC \\
\hline camphene & 955 & $-{ }^{a}$ & 0.8 & MS; LRI; RC \\
\hline sabinene & 977 & 0.4 & 0.7 & MS; LRI; RC \\
\hline$\beta$-pinene & 982 & 0.6 & 1.2 & MS; LRl; RC \\
\hline myrcene & 993 & 1.3 & 1.2 & 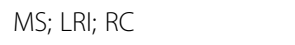 \\
\hline 3-octanol & 994 & $-{ }^{a}$ & $-{ }^{a}$ & MS; LRI; RC \\
\hline a-terpinene & 1020 & $-{ }^{a}$ & $-{ }^{a}$ & MS; LRI; RC \\
\hline p-cymene & 1028 & $-{ }^{a}$ & 0.3 & MS; LRI; RC \\
\hline limonene & 1032 & $-{ }^{a}$ & 2.7 & MS; LRI; RC \\
\hline 1,8-cineole & 1034 & 9.2 & 4.1 & MS; LRI; RC \\
\hline (Z)- $\beta$-ocimene & 1042 & 0.7 & $-{ }^{a}$ & MS; LRI; RC \\
\hline (E)-B-ocimene & 1052 & 0.5 & 1.5 & MS; LRl; RC \\
\hline$\gamma$-terpinene & 1063 & $-{ }^{a}$ & $-{ }^{a}$ & MS; LRI; RC \\
\hline cis-sabinene hydrate & 1070 & $-{ }^{a}$ & $-{ }^{a}$ & MS; LRI; RC \\
\hline terpinolene & 1090 & 0.2 & 0.4 & MS; LRI; RC \\
\hline linalool & 1101 & 52.1 & 1.2 & MS; LRl; RC \\
\hline nonanal & 1104 & $-{ }^{a}$ & $-{ }^{a}$ & MS; LRI; RC \\
\hline pentylisovalerate & 1108 & 0.1 & $-{ }^{a}$ & $M S ;$ LRI \\
\hline 1-octen-3-yl acetate & 1111 & 0.1 & 0.4 & 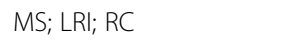 \\
\hline cis-p-menth-2-en-1-ol & 1123 & $-{ }^{a}$ & $-{ }^{a}$ & MS; LRI \\
\hline 3-octyl acetate & 1126 & 0.2 & $-{ }^{a}$ & MS; LRI; RC \\
\hline a-campholenal & 1127 & $-{ }^{a}$ & 0.5 & $M S ;$ LRI \\
\hline camphor & 1145 & $-{ }^{a}$ & 1.1 & MS; LRI; RC \\
\hline trans-verbenol & 1147 & $-{ }^{a}$ & 0.5 & MS; LRI; RC \\
\hline S-terpineol & 1172 & 0.2 & $-{ }^{a}$ & MS; LRI \\
\hline 4-terpineol & 1179 & 0.1 & 0.5 & MS; LRI; RC \\
\hline a-terpineol & 1191 & 5.7 & 4.9 & 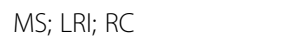 \\
\hline cis-dihydrocarvone & 1195 & $-{ }^{a}$ & $-{ }^{a}$ & MS; LRI; RC \\
\hline trans-carveol & 1219 & $-{ }^{a}$ & 0.4 & MS; LRI; RC \\
\hline (Z)-3-hexenyl isovalerate & 1238 & $-{ }^{a}$ & $-{ }^{a}$ & MS; LRI; RC \\
\hline pulegone & 1239 & 0.2 & $-{ }^{a}$ & 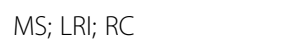 \\
\hline neral & 1242 & $-{ }^{a}$ & 0.2 & MS; LRI; RC \\
\hline carvone & 1244 & $-{ }^{a}$ & 0.3 & MS; LRI; RC \\
\hline linalyl acetate & 1259 & 19.1 & $-{ }^{a}$ & MS; LRI; RC \\
\hline bornyl acetate & 1287 & $-{ }^{a}$ & 3.1 & MS; LRI; RC \\
\hline dihydroedulan IA & 1292 & $-{ }^{a}$ & $-{ }^{a}$ & $M S ;$ LRI \\
\hline isodihydrocarvyl acetate & 1329 & $-{ }^{a}$ & $-{ }^{a}$ & MS; LRI \\
\hline a-terpinyl acetate & 1352 & $-{ }^{a}$ & 47.4 & MS; LRI; RC \\
\hline cis-carvyl acetate & 1364 & $-{ }^{a}$ & $-{ }^{a}$ & $M S ;$ LRI; RC \\
\hline neryl acetate & 1365 & 1.8 & 9.6 & MS; LRI; RC \\
\hline geranyl acetate & 1383 & 3.6 & 0.9 & MS; LRI; RC \\
\hline$\beta$-elemene & 1392 & $-{ }^{a}$ & $-a^{a}$ & $M S ;$ LRI \\
\hline (Z)-jasmone & 1395 & $-{ }^{a}$ & $-{ }^{a}$ & MS; LRI; RC \\
\hline
\end{tabular}


Table 3 Chemical composition of the essential oils extracted from the leaves of O. basilicum and T. algeriensis (Continued)

\begin{tabular}{|c|c|c|c|c|}
\hline Constituents & LRI & $\begin{array}{l}\text { O. basilicum } \\
\text { (\%) }\end{array}$ & $\begin{array}{l}\text { T. algeriensis } \\
\text { (\%) }\end{array}$ & Method of identification \\
\hline$\beta$-caryophyllene & 1419 & 1.0 & 0.6 & MS; LRl; RC \\
\hline$\beta$-copaene & 1430 & $-{ }^{a}$ & $-{ }^{a}$ & $M S ;$ LRI \\
\hline aromadendrene & 1440 & $-{ }^{a}$ & $-{ }^{a}$ & MS; LRI; RC \\
\hline a-humulene & 1455 & 0.1 & $-{ }^{a}$ & MS; LRI; RC \\
\hline (E)- $\beta$-farnesene & 1458 & 0.1 & $-{ }^{a}$ & MS; LRI; RC \\
\hline cis-muurola-4(14), 5-diene & 1463 & 0.1 & $-{ }^{a}$ & $M S ;$ LRI \\
\hline germacrene D & 1482 & $-{ }^{a}$ & 0.6 & $M S ;$ LRI \\
\hline bicyclogermacrene & 1496 & $-{ }^{a}$ & - & $M S ;$ LRI \\
\hline germacrene A & 1505 & $-{ }^{a}$ & $-{ }^{a}$ & MS; LRI \\
\hline$\delta$-cadinene & 1524 & $-{ }^{a}$ & $-{ }^{a}$ & $M S ;$ LRI \\
\hline (E)-a-bisabolene & 1542 & $-{ }^{a}$ & 0.2 & $M S ;$ LRI \\
\hline (E)-nerolidol & 1564 & $-{ }^{a}$ & 3.5 & $M S ;$ LRI \\
\hline spathulenol & 1577 & $-{ }^{a}$ & $-{ }^{a}$ & $M S ;$ LRI \\
\hline caryophyllene oxide & 1582 & 0.1 & 0.9 & MS; LRl; RC \\
\hline viridiflorol & 1591 & 0.4 & $-{ }^{a}$ & $M S ;$ LRI \\
\hline 1, 10-di-epi-cubenol & 1615 & 0.1 & $-{ }^{a}$ & $M S ;$ LRI \\
\hline T-cadinol & 1641 & $-a^{a}$ & $-a^{a}$ & $M S ;$ LRI \\
\hline T-muurolol & 1642 & $-{ }^{a}$ & $-{ }^{a}$ & MS; LRI \\
\hline Monoterpene hydrocarbons & & 4.0 & 15.6 & \\
\hline Oxygenated monoterpenes & & 92.0 & 74.7 & \\
\hline Sesquiterpene hydrocarbons & & 1.3 & 1.4 & \\
\hline Oxygenated sesquiterpenes & & 0.6 & 4.4 & \\
\hline Apocarotenes & & 0.0 & 0.0 & \\
\hline Non-terpene derivatives & & 0.4 & 0.4 & \\
\hline Total identified & & 98.3 & 96.5 & \\
\hline
\end{tabular}

a: not detected in the sample

${ }^{b}$ method of identification: MS Mass spectrum, $L R I$ Linear retention index, RC Reference compound

monitored spectrophotometrically and is utilized for the determination of antioxidant capacity $[28,29]$. To evaluate the different antioxidant potentials of the phenolic extracts and essential oils, their $\mathrm{IC}_{50}$ values, as determined by the DPPH assay, were compared to the $\mathrm{IC}_{50}$ of the reference compound ascorbic acid (vitamin C) in $\mathrm{mg} / \mathrm{mL}$. The results are summarized in Table 4. The ethanolic extracts demonstrated excellent DPPH radical-scavenging activities. Generally, the activity associated with the $O$. basilicum extract was stronger than that associated with the $T$. algeriensis extract, and both extracts had less activity than ascorbic acid $\left(\mathrm{IC}_{50}=0.002 \pm 3.826 \times 10^{-6} \mathrm{mg} / \mathrm{mL}\right)$ . For the essential oils, the strongest activity was associated with the T. algeriensis oil, with an $\mathrm{IC}_{50}$ value of $1.437 \mathrm{mg} /$ $\mathrm{mL}$, followed by BHA ( $\mathrm{IC}_{50}$ of $\left.1.437 \mathrm{mg} / \mathrm{mL}\right)$ and the $O$. basilicum oil ( $\mathrm{IC}_{50}$ of $16.296 \mathrm{mg} / \mathrm{mL}$ ). However, all examined samples were less active than the standard antioxidant ascorbic acid.

\section{ABTS assay}

The results of this assay are shown in Table 4. Based on the results, the EOs appeared to possess higher anti-free radical activity than the ethanolic extracts. The ethanolic extract of $O$. basilicum demonstrated higher antiradical activity than the ethanolic extract of $T$. algeriensis, which may be attributed to its high phenolic content (rutin, vanillic acid, epicatechin); such compounds are responsible for trapping the cation radical $\mathrm{ABTS}^{\bullet+}$ by providing $\mathrm{H}^{+}$.

\section{Ferric-reducing antioxidant power test}

Table 4 shows the AEAC values for the ethanolic extracts and essential oils obtained from the studied plants, together with that of BHA, which was chosen as the standard antioxidant. Considerable attention has been focused on the determination of total antioxidant capacity using the antioxidant activity of ascorbic acid in terms of equivalence and reflected in the AEAC, defined 
Table $4 \mathrm{IC}_{50}(\mathrm{DPPH}), \mathrm{C}_{50}$ (ABTS), AEAC (FRAP assay), AEAC (Phosphomolybdenum assay) of the extracts, ascorbic acid, and BHA

\begin{tabular}{llllll}
\hline Plant/Control & Extract & $\begin{array}{l}\mathrm{IC}_{50}(\mathrm{DPPH}) \\
(\mathrm{mg} / \mathrm{mL})\end{array}$ & $\begin{array}{l}\mathrm{I}_{50}(\mathrm{ABTS}) \\
(\mathrm{mg} / \mathrm{mL})\end{array}$ & $\begin{array}{l}\text { AEAC-FRAP assay } \\
(\mu \mathrm{g} / \mathrm{mL})\end{array}$ & $\begin{array}{l}\text { AEAC- Phosphomolybdenum assay } \\
(\mathrm{mg} / \mathrm{mL})\end{array}$ \\
\hline Ocimum basilicum & $\mathrm{EE}$ & $0.679 \pm 0.0383^{\mathrm{a}}$ & $0.970 \pm 0.022^{\mathrm{a}}$ & $3.657 \pm 0.009^{\mathrm{a}}$ & $0.005 \pm 0.0003^{\mathrm{a}}$ \\
& $\mathrm{EO}$ & $16.296 \pm 0.394^{\mathrm{c}}$ & $0.6870 \pm 0.0203^{\mathrm{a}}$ & $0.003 \pm 0.0007^{\mathrm{c}}$ & $0.760 \pm 0.001^{\mathrm{c}}$ \\
Thymus algeriensis & $\mathrm{EE}$ & $1.560 \pm 0.010^{\mathrm{a}}$ & $1.743 \pm 0.195^{\mathrm{a}}$ & $0.897 \pm 0.064^{\mathrm{d}}$ & $0.007 \pm 0.0006^{\mathrm{a}}$ \\
& $\mathrm{EO}$ & $1.437 \pm 4.51 \mathrm{E}-05^{\mathrm{d}}$ & $0.8960 \pm 0.203^{\mathrm{a}}$ & $1.387 \pm 0.265^{\mathrm{d}}$ & $0.432 \pm 0.001^{\mathrm{c}}$ \\
Ascorbic acid & & $0.002 \pm 3.826 \mathrm{E}-06^{\mathrm{b}}$ & $0.001 \pm 5.13 \mathrm{E}-05^{\mathrm{b}}$ & $\mathrm{ND}$ & $\mathrm{ND}$ \\
Vitamin E & $\mathrm{ND}$ & $\mathrm{ND}$ & $\mathrm{ND}$ & $0.674 \pm 0.057^{\mathrm{b}}$ \\
Trolox & $\mathrm{ND}$ & $0.003 \pm 3.35 \mathrm{E}-05^{\mathrm{b}}$ & $\mathrm{ND}$ & $\mathrm{ND}$ \\
BHA & $1.685 \pm 0.658^{\mathrm{b}}$ & $\mathrm{ND}$ & $1000 \pm 0.047^{\mathrm{b}}$ & $\mathrm{ND}$
\end{tabular}

EE Ethanol extract

EO Essential oil

ND Not determined

Each value in the table is represented as mean $\pm \mathrm{SD}(n=3)$. In the same column, means not sharing the same letter are significantly different at $P<0.05$

probability level in each column

as the concentration of ascorbic acid $(\mu \mathrm{g} / \mathrm{mL})$ that gives an antioxidant power equivalent to that of a concentration of $1 \mathrm{mg} / \mathrm{mL}$ of the EO and EE. A high AEAC indicates a notable antioxidant capacity [30]. Relative to that of the positive control, the EE of O. basilicum had the most potent activity $\left(\mathrm{IC}_{50}\right.$ of $\left.3.657 \pm 0.009 \mu \mathrm{g} / \mathrm{mL}\right)$, followed by the $\mathrm{EO}$ of $T$. algeriensis $\left(\mathrm{IC}_{50}\right.$ of $1.387 \pm$ $0.265 \mu \mathrm{g} / \mathrm{mL}$ ). However, the EE of T. algeriensis demonstrated a lower antioxidant potential, with an $\mathrm{IC}_{50}$ of $0.897 \pm 0.064 \mu \mathrm{g} / \mathrm{mL}$. Notably, the EOs from both plants demonstrated poor $\mathrm{Fe}^{2+}$ reducing potential relative to the standard antioxidant BHA.

\section{Phosphomolybdenum assay}

The different extracts of $O$. basilicum and T. algeriensis were also used to determine their antioxidant capacities from the formation of the green phosphomolybdenum complex. The antioxidant activities of the extracts were referenced to that of ascorbic acid in terms of equivalence by calculating the AEAC value. This method is based on the reduction of molybdenum from an oxidation state of VI to an oxidation state of $\mathrm{V}$ in the presence of an antioxidant. This reduction is materialized by the formation of a greenish complex detectable in the visible region at $695 \mathrm{~nm}$ at an acidic $\mathrm{pH}$ [31]. The results indicate that under the applied experimental conditions, the $O$. basilicum and T. algeriensis EOs are potent antioxidants, while their phenolic extracts have the lowest potential to reduce molybdenum. The Ocimum basilicum oil recorded the highest AEAC, which surpassed vitamin E's AEAC under the same experimental conditions. This result may be attributed to the chemical composition of the O. basilicum oil, which mainly contained 92\% oxygenated monoterpenes, with linalool as the predominant compound [32].

\section{Antimicrobial activity}

The ethanolic extracts of $O$. basilicum and T. algeriensis as well as their essential oils were evaluated in terms of potential antimicrobial activity against a group of pathogenic microorganisms, comprising gram-positive and gram-negative bacteria and a fungus (Table 5). Superior antimicrobial activity was observed against the gram-positive bacteria examined in this study, while both plant extracts and essential oils demonstrated moderate activities against gramnegative bacteria. Interestingly, the antimicrobial activities observed after essential oil treatment appeared to be generally more potent than those associated with the ethanolic extracts of $O$. basilicum and T. algeriensis. As shown in Table 5, moderate antifungal activity was associated with both the ethanolic extracts and essential oils from O. basilicum and T. algeriensis when examined against Candida glabrata and Candida albicans. Numerous literature studies have provided support for the antimicrobial activities of several of the compounds in the O. basilicum and T. algeriensis ethanolic extracts and essential oils. For instance, quercetin has been reported as a very efficient antimicrobial compound against several pathogenic gram-positive and gram-negative bacteria [23-25]. In addition, it has been shown that the antibacterial activities of flavonoids, such as quercetin, were effectively enhanced in the presence of rutin, a major component of the ethanolic extracts of both plants, although rutin did not show activity on its own [33].

\section{Anticancer activity}

The in vitro antiproliferative effects of the ethanolic extracts and essential oils from O. basilicum and T. algeriensis were assessed on five human cancer cell lines, namely human breast adenocarcinoma MCF-7 and MDA-MB-231 cell lines, the human adenocarcinoma HeLa cell line, the human prostate cancer PC3 cell line, and the human leukaemia K56S cell line. The observed antiproliferative activities 
Table 5 Antimicrobial activities of O. basilicum and T. algeriensis ethanolic extracts and essential oils against eight pathogenic microorganisms expressed as MIC $(\mu \mathrm{g} / \mathrm{mL})$ values

\begin{tabular}{|c|c|c|c|c|c|c|c|c|}
\hline Extract & S. epidermidis & S. aureus & B. subtilis & E. coli & K. pneumoniae & p. aeruginosa & C. albicans & C. glabrata \\
\hline $\begin{array}{l}\text { O.basilicum } \\
E E\end{array}$ & 128 & 128 & 64 & 128 & 256 & 256 & 64 & 128 \\
\hline $\begin{array}{l}\text { T.algeriensis } \\
E E\end{array}$ & 128 & 64 & 64 & 256 & 256 & 512 & 128 & 128 \\
\hline $\begin{array}{l}\text { O.basilicum } \\
\text { EO }\end{array}$ & 32 & 32 & 16 & 64 & 128 & 256 & 32 & 32 \\
\hline $\begin{array}{l}\text { T.algeriensis } \\
\text { EO }\end{array}$ & 32 & 32 & 32 & 64 & 256 & 512 & 64 & 32 \\
\hline Ampicillin & 2 & 2 & 4 & 16 & 64 & 128 & - & - \\
\hline Amphotericin B & - & - & - & - & - & - & 2 & 2 \\
\hline
\end{tabular}

on the examined cell lines are presented in Table 6 as $\mathrm{LD}_{50}$ values, referring to the concentration at which cancer cell survival was reduced by $50 \%$. The dose-dependent curves obtained by nonlinear regression were used to calculate the $\mathrm{LD}_{50}$ values. Doxorubicin, a well-known anticancer agent, was used as a positive control and demonstrated $\mathrm{LD}_{50}$ values ranging from $1-20 \mu \mathrm{g} / \mathrm{mL}$ against the different cancer cell lines used in this study. Generally, the essential oils from both plants were much more effective in suppressing cancer cell growth than the ethanolic extracts.

The phytochemical constituents of the essential oils under investigation include many of the most active naturally existing anticancer phytochemicals, such as 1,8 cineole and linalool [23-25]. Similarly, polyphenols, such as quercetin, are often reported to exert anticancer activities against various cancer cell lines [25]. Remarkably, the numerous phytochemical constituents in essential oils and their potency to prevent cancer cell growth at fairly low concentrations may be attributed to the additive or synergistic effects of the different components.

\section{Conclusion}

In summary, the chemical composition of ethanolic extracts and essential oils from Ocimum basilicum and Thymus algeriensis cultivated in the Algerian Saharan Atlas was reported for the first time in this study. A rich flavonoid content of the EEs of both plants was revealed by

Table 6 Antiproliferative activities of O. basilicum and T. algeriensis ethanolic extracts and essential oils on five human cancer cell lines, exposure time $48 \mathrm{~h}$. $L_{50}(\mu \mathrm{g} / \mathrm{mL})$ values are shown $\pm S D$

\begin{tabular}{llllll}
\hline Extract & MCF-7 & MDA-MB-231 & HeLa & PC3 & K562 \\
\hline $\begin{array}{l}\text { O. basilicum } \\
\text { EE }\end{array}$ & $>10,000$ & $>10,000$ & $>10,000$ & $>10,000$ & $>10,000$ \\
$\begin{array}{l}\text { T. algeriensis } \\
\text { EE }\end{array}$ & $>10,000$ & $>10,000$ & $>10,000$ & $>10,000$ & $>10,000$ \\
$\begin{array}{l}\text { O. basilicum } \\
\text { EO }\end{array}$ & $1090 \pm 64$ & $1012 \pm 44$ & $1052 \pm 38$ & $1028 \pm 78$ & $929 \pm 18$ \\
$\begin{array}{l}\text { T. algeriensis } \\
\text { EO }\end{array}$ & $647 \pm 16$ & $715 \pm 22$ & $746 \pm 19$ & $1067 \pm 96$ & $300 \pm 13$ \\
\hline
\end{tabular}

HPLC analysis of the phenolic compounds. GC-MS analysis demonstrated that linalool (52.1\%) and linalyl acetate (19.1\%) are the major compounds in the essential oil from O. basilicum, while $\alpha$-terpinyl acetate (47.4\%), neryl acetate $(9.6 \%)$, and $\alpha$-pinene $(6.8 \%)$ were identified as the major compounds in the essential oil from $T$. algeriensis. Additionally, diverse bioactivities of the ethanolic extracts and essential oils from both plants were observed against a range of clinically relevant strains of microorganisms, with enhanced activities against gram-positive bacteria. The essential oils from both plants were much more potent in inhibiting cancer cell growth than the ethanolic extracts. Moderate antioxidant activities were elucidated, suggesting their potential for use in pharmaceutical industries and food production technologies.

\section{Abbreviations \\ $A_{c}$ : Absorbance of the control reaction; AEAC: Ascorbic acid equivalent antioxidant capacity; As: Absorbance of the test sample; EE: Ethanolic extract; EO: Essential oil; GAE: Gallic acid equivalents; GC-EIMS: Gas chromatography with electron impact mass spectrometry; LD: Lethal dose; MIC: Minimum inhibitory concentration; RE: Rutin equivalents}

\section{Acknowledgements}

Not applicable.

\section{Authors' contributions}

MR and SB designed and performed the experiments, interpreted the results, drafted the manuscript and revised it. BB and AG collected the plants, isolated the essential oils, characterized the antioxidant activities of the oils, drafted the manuscript and participated in the design of the study. AR and FG prepared and evaluated the results and participated in writing the manuscript. OK and RM conducted the chemical composition analysis, performed the statistical analysis and participated in drafting the manuscript. All authors read and approved the final manuscript.

\section{Funding}

This research was supported by The Deanship of Scientific Research at The University of Jordan (1786) and The University of Laghouat (Algeria). The funding body had no role in the study design, performance, data collection and analysis, decision to publish, or preparation/writing of the manuscript.

Availability of data and materials

The data that support the findings of this study are available from the corresponding author on reasonable request.

Ethics approval and consent to participate

Not applicable because the research did not involve human participants. 


\section{Consent for publication}

Not applicable.

\section{Competing interests}

The authors declare that they have no competing interests.

\section{Author details}

'Laboratory of Process Engineering, Faculty of Technology, Laghouat University, 03000 Laghouat, Algeria. ${ }^{2}$ Dipartimento di Farmacia, Università di Pisa, Via Bonanno 6, 56126 Pisa, Italy. ${ }^{3}$ Department of Biology, Faculty of Science and Arts, Pamukkale University, Denizli, Turkey. ${ }^{4}$ Department of Pharmaceutical Sciences, School of Pharmacy, The University of Jordan, Queen Rania Street, Amman 11942, Jordan.

Received: 3 February 2019 Accepted: 10 June 2019

Published online: 21 June 2019

\section{References}

1. Ksouri R, Megdiche Ksouri W, Jallali I, Debez A, Magné C, Hiroko I, Abdelly C Medicinal halophytes potent source of health promoting biomolecules with medical, nutraceutical and food applications. Crit Rev Biotechnol. 2011;32:289-326.

2. Stanojević D, Čomić L, Stefanović O, Solujić S, Sukdolak S. In vitro synergistic antibacterial activity of Melissa officinalis L. and some preservatives. Span J Agric Res. 2010;8:109-15.

3. Pop A, Muste S, Muresan C, Pop C, Salanta L. Comparative study regarding the importance of sage (Salvia officinalis L.) in terms of antioxidant capacity and antimicrobial activities. Hop Med Plants. 2013;21:1-2.

4. Stević T, Berić T, Šavikin M, Soković M, Gođevac I, Dimkić I, Stanković S Antifungal activity of selected essential oils against fungi isolated from medicinal plant. Ind Crop Prod. 2014;55:116-22.

5. Kamdem JP, Adeniran A, Boligon AA, Klimaczewski CV, Elekofehinti OO, Hassan W, Ibrahim M, Waczuk EM, Meinerz DF, Athayde ML. Antioxidant activity, genotoxicity and cytotoxicity evaluation of lemon balm (Melissa officinalis L.) ethanolic extract: its potential role in neuroprotection. Ind Crop Prod. 2013;51:26-34

6. Lin JT, Chen YC, Lee YC, Rolis Hou CW, Chen FL, Yang DJ. Antioxidant, antiproliferative and cyclooxygenase-2 inhibitory activities of ethanolic extracts from lemon balm (Melissa officinalis L.) leaves. LWT-Food Sci Technol. 2012;49:1-7.

7. De Sousa AC, Alviano DS, Blank AF, Alves PB, Alviano CS, Gattass CR. Melissa officinalis L. essential oil. Antitumoral and antioxidant activities. J Pharm Pharmacol. 2004;56:677-81.

8. De P, Baltas M, Bedos-Belval F. Cinnamic acid derivatives as anticancer agents-a review. Curr Med Chem. 2012;18:1672-703.

9. Paton A, Harley RM, Harley MM. Ocimum-an overview of relationships and classification. In: Holm Y, Hiltunen R, editors. Ocimum. Medicinal and aromatic plants-industrial profiles. Amsterdam: Harwood Academic; 1999. p. 1-38.

10. Simon JE, Morales MR, Phippen WB, Vieira RF, Hao Z. Basil: a source of aroma compounds and a popular culinary and ornamental herb. In: Janick J, editor. Perspectives on new crops and new uses: biodiversity and agricultural sustainability. Alexandria: ASHS Press; 1999. p. 499-505.

11. Lee SJ, Umano K, Shibamoto T, Lee KG. Identification of volatile components in basil (Ocimum basilicum L.) and thyme leaves (Thymus vulgaris L.) and their antioxidant properties. Food Chem. 2005:91:131-7.

12. Chalchat JC, Ozcan MM. Comparative essential oil composition of flowers, leaves and stems of basil oil (Ocimum basilicum L.) used as herb. Food Chem. 2008;110:501-3.

13. Cronquist A. The evolution and classification of flowering plants. New York: The New York Botanical Garden; 1988.

14. Zaidi MA, Crow SA. Biologically active traditional medicinal herbs from Balochistan. J Ethnopharmacol. 2005;96:331-4.

15. Ismaili $H$, Milella L, Frih-Tetouani S, Ilidrissi A, Camporese A, Sosa S, Altinier G, Della Loggia R, Aquino R. In vivo topical anti-inflammatory and in vitro antioxidant activities of two extracts of Thymus satureioides leaves. J Ethnopharmcol. 2004;91:31-6

16. Thompson JD, Chalchat JC, Michet A, Linhart YB, Ehlers B. Qualitative and quantitative variation in monoterpene cooccurrence and composition in the essential oil of Thymus vulgaris chemotypes. J Chem Ecol. 2003;29:859-80.

17. Vernon LS, Orthofer R, Lamuela-Raventós RM. Analysis of total phenols and other oxidation substrates and antioxidants by means of folin-ciocalteu reagent. Methods Enzymol. 1999;299:152-78.
18. Boulanouar B, et al. Antioxidant activities of eight Algerian plant extracts and two essential oils. Ind Crop Prod. 2013:46:85-96.

19. Caponio F, Alloggio V, Gomesb T. Phenolic compounds of virgin olive oil; influence of paste preparation techniques. Food Chem. 1999:64:203-9.

20. Re R, Pellegrini N, Proteggente A, Pannala A, Yang M, Rice-Evans C. Antioxidant activity applying an improved ABTS radical cationdecolorization assay. Free Radic Biol Med. 1999;26(9-10):1231-7.

21. Oyaizu M. Studies on products of browning reaction. Japanese J Nutr Diet. 1986:44(6):307-15

22. Prieto P, Pineda M, Anguilar M. Spectrophotometric quantitation of antioxidant capacity through the formation of a phosphomolybdenum complex: specific application to the determination of vitamin E. Anal Biochem. 1999:269:337-41.

23. Bardaweel SK, Hudaib MM, Tawaha KA, Bashatwah RM. Studies on the in vitro antiproliferative, antimicrobial, antioxidant, and acetylcholinesterase inhibition activities associated with Chrysanthemum coronarium essential oil. Evid Based Complement Alternat Med. 2015;2015:790838.

24. Bardaweel SK, Bakchiche B, ALSalamat HA, Rezzoug M, Gherib A, Flamini G. Chemical composition, antioxidant, antimicrobial and Antiproliferative activities of essential oil of Mentha spicata L.(Lamiaceae) from Algerian Saharan atlas. BMC Complement Alternat Med. 2018;18:201.

25. Bouziane A, Bakchiche B, Dias M, Barros L, Ferreira I, AlSalamat H, Bardaweel S. Phenolic compounds and bioactivity of Cytisus villosus Pourr. Mol. 2018; 23:1994-2006.

26. Dudai N, Li G, Shachter A, Belanger F, Chaimovitsh D. Heredity of phenylpropenes in sweet basil (Ocimum basilicum L.) chemotypes and their distribution within an F2 population. Plant Breed. 2018;137:443-9.

27. Mehalaine S, Belfadel O, Menasria T, Messaili A. Chemical composition and antibacterial activity of essential oils of three medicinal plants from Algerian semi-arid climatic zone. Phytothérapie. 2017:1-9. https://doi.org/10.1007/ s10298-017-1143-y.

28. Rødtjer A, Skibsted LH, Andersen ML. Antioxidative and prooxidative effects of extracts made from cherry liqueur pomace. Food Chem. 2006:99(1):6-14.

29. Mishra K, Ojha H, Kumar Chaudhury N. Estimation of antiradical properties of antioxidants using DPPH assay: a critical review and results. Food Chem. 2012;130:1036-43.

30. Amarowicz R, Troszyńska A. Nnina Baryłko-pikielna, Fereidoon Shahidl. Polyphenolics extracts from legume seeds: correlations between total antioxidant activity, total phenolics content, tannins content and astringency. J Food Lipids. 2004;11(4):278-86.

31. Lu Y, Foo Y. Antioxidant activities of polyphenols from sage (Salvia officinalis). Food Chem. 2001:75:197-202.

32. Jamali CA, El-Bouzidi L, Bekkouche K, Lahcen $H$, Markouk M, Wohlmuth $H$, Abbad A. Chemical composition and antioxidant and Anticandidal activities of essential oils from different wild Moroccan Thymus species. Chem Biodivers. 2012;9(6):1188-97.

33. Arima H, Ashida H, Danno G. Rutin-enhanced antibacterial activities of flavonoids against Bacillus cereus and Salmonella enteritidis. Biosci Biotechnol Biochem. 2002;66(5):1009-14.

\section{Publisher's Note}

Springer Nature remains neutral with regard to jurisdictional claims in published maps and institutional affiliations.

Ready to submit your research? Choose BMC and benefit from

- fast, convenient online submission

- thorough peer review by experienced researchers in your field

- rapid publication on acceptance

- support for research data, including large and complex data types

- gold Open Access which fosters wider collaboration and increased citations

- maximum visibility for your research: over $100 \mathrm{M}$ website views per year

At $\mathrm{BMC}$, research is always in progress.

Learn more biomedcentral.com/submissions 